\title{
Idræt og Arkitektur - krop, sprog og socialisering
}

Af Søren Nagbøl

„Hvad der på forhånd adskiller den dårligste bygmester fra de bedste bier er, at han har bygget cellen $i$ sit hoved for han bygger den $i$ voks" (Karl Marx)

\section{Om menneskeskabte symboler og kommunikation af viden}

Menneskene er - om de er sorte, røde, gule eller hvide-medlem af en ensartet art, menneskeslægten, og samtidig er de medlem af forskellige samfund. Her står vi overfor et problem og en udfordring, som er udpræget menneskelig, og som ikke påvirker trækfugle, ulve eller andre dyr, der krydser menneskeskabte grænser. For deres livsførelse foregår bag om de symboliseringsprocesser, vi kalder planlægning og kulturel kommunikation. De ligger så at sige fastlagt $\mathrm{i}$ deres biologiske forudsætninger.

Menneskene kommunikerer ved hjælp af symboler, som er skabt af mennesker, og er forskellige fra samfund til samfund. De er ikke som ved forskellige dyrearter karakteriseret ved arten, men ved det samfund, de er vokset op i. Det sprog, de skikke og den viden som mennesker dermed er i stand til at akkumulere, bevare og formidle fra den ene generation til den næste. Den er på den anden side ikke mulig at fiksere genetisk. Det er en viden, der opstår og tilegnes gennem en lang læreproces i det samfund man vokser op i. Desuden er sprogets struktur og betydning determine- ret af dets sociale funktion og den kulturelle arv og det civilisatoriske mønster, som er karakteristisk for det pågældende samfund. Menneskene besidder en evne til at kommunikere, men optræder overfor hinanden med meget forskellige sociale og kulturelle forudsætninger. Det betyder, at det biologisk ensartede, arten menneske, står indbyrdes overfor hinanden med en meget høj grad af social mangfoldighed. Det, at vi alle er i stand til at benytte sprog og udvikle symboler, betyder, at menneskene på den ene side optræder overfor hinanden som enheder, på den side anden som en helhed af forskelligheder. De sanselige symboliseringsprocesser og sproget kan således tjene til at integrere eller splitte - lukke inde eller ude. ${ }^{1}$

\section{Om idrat og arkitektur}

Fra fødsel til død er idræt og arkitektur en uadskillelig helhed i alle menneskers liv. Det bliver tydeligt, når man ser på begreberne idræt og arkitektur i de gængse opslagsværker.

Det gamle nordiske udtryk idræt betyder i følge Den Store Danske Ordbog; kraftfuldt, gerning, handling eller håndværk. I dag opfattes begrebet idræt som det overordnede begreb for bevægelse, leg, motion og sport.

Idrætsbegrebet hænger efter min opfattelse også sammen med de første oplevel- 
ser, hvor samspillet mor og barn skal lykkes for, at det kan overleve. Menneskebarnet er forbundet med arkitekturen, fra det begynder at fumle, lege, gå i skole, gå på arbejde, og helt ind i alderdommen til det dør og bliver begravet.

Ser vi på begreberne arkitekt og arkitektur, så står der i Nudansk ordbog (1979): Arkitekt: bygmester, tømrer, Arkitektur bygningskunst. I gyldendals fremmedordbog (1984) kan man læse under arkitekt (håndværker) person der fagligt beskæftiger sig med planlægningen af landskaber, haver, byer, udformning af vore fysiske omgivelser: bygninger, kunstindustri - alle produkter o.a.

Arkitekturen står som et legemliggjort udtryk for tilstedeværelse. Det er netop fordi, at arkitekturen dækker hele tilværelsen, at den bliver kaldt moderkunsten. Som ingen anden kunstart er den i sit væsen intersubjektiv og har netop til hensigt at give menneskene fodfæste i tid og rum. Arkitektur handler ikke kun om fodfæste. Den er også bevægelse, så derfor menes der med fodfæste ikke et fast ståsted, men en stedernes struktur, som kan åbne eller lukke for forskellige former for livsudfoldelse. Idræt er som livsudfoldelse i bevægelse afhængig af stedernes beskaffenhed. Det handler om tid, krop, bevægelse og rum, og de dermed forbundne livsbetingelser. Begreberne idræt og arkitektur har i menneskers praksis fælles forudsætninger, de optræder som en helhed og udgør således en syntese i alles liv.

Tematiseringen af forholdet mellem arkitektur og idræt handler om at vise, hvorledes samspillet mellem idrætsaktiviteter og arkitektoniske iscenesættelser kan bidrage til en forståelse af idrættens og arkitekturens betydning for menneskers socialisering og kulturelle udvikling.
Det drejer sig i den forbindelse om at skabe en forståelse mellem dem, der skaber, og dem der bruger arkitektoniske iscenesættelser. At udvikle viden og erkendelse i det felt, hvor arkitekturens materielle- og kropslige spor krydser hinanden. Gennem interdisciplinær erfaring og videnssociologisk refleksion at skærpe bevidstheden om de sanselige vilkår arkitekturen og byen rummer, og i den forbindelse fremme vores forståelse for betydningen af menneskers møde med samfundsmæssige symboliseringsprocesser. De iscenesættelser der er rammen om ritualer og ceremonier, og som bag om sproget inddrager kroppen og sansernes mobilitet. Det handler om at synliggøre menneskers socialisering, civilisering og selvopfattelse i det moderne velfærdssamfund. Det skal ske i mødet mellem tradition og bevægelse, mellem dem der har viden og erfaringer, og den ungdom der har vitaliteten og styrken til at skabe nye visioner.

\section{Derfor arven fra Steen Eiler Rasmussen}

Ved en genlæsning af Steen Eiler Rasmussens forfatterskab er jeg blevet overrasket over, hvor stor betydning beskæftigelsen med idræt har haft for hans arkitekturforståelse. Det er indsigter, der viser den enorme betydning, samspillet mellem arkitektur, håndværk og idræt har haft for den måde Steen Eiler Rasmussen oplever, erkender og skriver om arkitektur og byplanlægning. Det spores umiddelbart i hans parklandskabs- og naturbeskrivelser.

I bogen, London fra 1934, starter han kapitlet om Londons Parker således:

"Den londonske Park er skabt som Ramme om et frit Udendørsliv «, og han fortsatter. »På fastlandet er man mange Steder stadig 
tilbøjelig til at betragte det som deres vigtigste Opgave at vare aabne Arealer, hvor der kan vare bedre Luft end i de beklumrede Boligkvarterer. Men for Englanderne er de offentlige Havers vigtigste Mission at give Befolkningen Lejlighed til at rore sig $i$ et sundt Friluftsliv. De moderne londonske Parkers udvikling er derfor nфje knyttet til den engelske Sports Udvikling; deres Udformning er bestemt af den folkelige Idrats Krav. $\ll^{2}$

Det er interessant at Steen Eiler Rasmussen i hele afsnittet om Londons Parker hovedsageligt beskæftiger sig med sporten og forlystelsernes udvikling i England.

Parkerne bliver ikke anskuet som landskabskunst, men på baggrund af det liv der udvikles, de sanselige og oplevelsesmæssige kvaliteter der udspringer af parkernes mission for den engelske befolkning. Han signaliserer dermed også forskellen mellem den traditionelle engelske landskabspark og den moderne verden, og hvad det betyder for væren og erkendelse.

»Den engelske Landskabspark var skabt af saadanne Folk, der elskede Koer og Hyrdeliv - isar gengivet i Porcelan; men deres Efterkommere $i$ det 19. Aarhundrede opdagede, at man ikke nojedes med at beskue de arkadiske Landskaber, man kunne gфre Brug af Haverne, bruge dem til at lege og drive sport $i$ «. ${ }^{3}$

Det fortsætter med, at legepladser breder sig udover hele byen. Og det betyder, at oplevelser ikke kun bliver knyttet til kunsten, men også til kropslige aktiviteter. Dermed får det barnlige i mennesket sin plads i landskabet. Der bliver plads til tankegymnastik og mulighed for uhæmmet at begive sig ind $\mathrm{i}$ fantasiens vidunderland.
Steen Eiler Rasmussens fremstilling af de landskabelige parkers historie, betragtet $\mathrm{i}$ lyset af den engelske sports udvikling, viser at der har eksisteret en smuk og nyttig vekselvirkning mellem kunsten og livet. Parken optræder ikke længere som et bille-

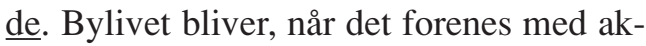
tiviteterne i parkerne omsat til en konkret opfattelse af virkeligheden.

»I det 19. Aarhundrede gik det Englanderen som H.C. Andersens lille Hjalmer I Eventyret om Ole Lukфje »Hjalmer stak Benene ind $i$ Maleriet, lige ind $i$ det hoje Graes, og der stod han. Solen skinnede mellem traernes grene ned på ham." Kunstnere som H.C. Andersen forberedte Udviklingen, og det, der for dem var Drom blev snart til Virkelighed. Man larte at sanse den reelle Verden på en storkere Maade end ved Malernes Billedsyn. ${ }^{4}$

Erkendelsen af virkeligheden bliver mere konkret og personlig, når man træder ud i den. Den bliver nærværende og rettet mod flere aspekter af livet.

»De har ikke faaet deres Syn bestemt af Kunsten, men foler meget mere oprindelig Samhorighed med Naturen. Hampstead Heath oplever de lige saa meget med Fodderne som med Øjnene. De er ikke paa Maleriudstilling. De foler sig først og fremmest ligesom den lille Hjalmer det dejlige Groes, som de gaar $i$ med Velbehag, naar de er sluppet ud fra gaderne. De ikke blot ser, men de foler Bakkernes Form, naar de mфdige overvinder Vanskelighederne og stiger op til Hojderne. Deroppe faar de en rig Løn i Form af den vide Udsigt: $i$ det altid skiftende Klima er det spandende at prøve, hvor langt man kan se idag. Al den Sport der drives paa Hampstead Heath, kan ses som et Fors $\phi g$ paa stadig intensivere at tilegne sig Naturen. " 5 
Man lærer med sådanne erfaringer at forbinde krop, tanke og virkelighed, som en del af bevægelsen. Forlade billedet og de tomme abstraktioner, men alligevel forholde sig til den reelle livsverden og de forandringer den ustandselig byder på. Det giver muligheden for umiddelbart at finde tilbage til spillet mellem fantasi og virkelighed. Det Steen Eiler Rasmussen viser med sine betragtninger over sammenhængen mellem sport og landskabsforståelse er, at bevægelsen i iscenesættelsen er forudsætningen for den helhedsopfattelse, som slår nye porte op for erkendelse af virkeligheden. Bevægelsen er et fundamentalt erkendelsespotentiale, en forudsætning for at fornemme arkitekturen og omgivelserne.

»Det sarlige ved sporten er jo netop ikke at man søger at naa til resultatet ved tankearbejde. Man opфver fornemmelsen for den rigtige metode, saa at man synes, man har den i sig og har lyst til at gфre det rigtige. ${ }^{6}$

Denne dialektiske opfattelse af forholdet mellem idrætsaktiviteter og arkitekturoplevelser får fundamental betydning for kronen på hans forfatterskab: $\mathrm{Om}$ at opleve arkitektur. I forordet står der:

»Det er en bog om hvordan vi fornemmer ting, der omgiver os ...

Jeg vil $i$ al beskedenhed prфve, at vise, hvad det er for et instrument arkitekturen spiller paa, vise hvor stort et register det har og derigennem aabne sindet for dets musik

Vil man demonstrere kunstens instrument, kan man ikke nфjes med som en fysiker at forklare dets mekanik. Man maa ligesom spille noget igennem paa det, saa man kan fornemme, hvad det bruges til. « ${ }^{7}$
Sammenhængen mellem hans og vores tema, idræt og arkitektur, bliver mere og mere konkret og forståelig, når man i artiklen Michelangelo og Fodbold fra 1939, kan læse:

»Det der giver den gode sportsmand, er ikke muskler, det er forst og fremmest fornemmelsen for rytmen $i$ hans sport.. Rytme er et af de ord man slider allermest paa for tiden. Det bruges isar $i$ forbindelse med moderne musik. Hvad folk mener, naar de bruger ordet, ved man ikke altid helt procist. Jeg vil forklare rytme som en regelmassig afveksling, der kan tjene til at lette udforelsen af et arbejde - eller ogsaa lette opfattelsen af en bevagelse. ${ }^{8}$

Menneskets følsomhed udvikler sig i lyset af deres aktiviteter. Det gælder især barnet, men også håndværkeren, idrætsudøveren og arkitekten, der føler sig knyttet til sit fag. Det kropslige forhold går igen i brugen.

Barnet lever sig paa en maade sammen med al slags legetøj, der udvider dets muligheder for at opleve omgivelserne. Hvis det sutter på fingeren og stikker den $i$ vejret, kan det morke, hvordan vinden er $i$ de lave luftlag, det selv bevager sig $i$. Men med en drage har det en foler langt ud $i$ atmosfaren. Det bliver eet med sjippetovet, med lobehjulet, med cyklen. Ved en mongde oplevelser larer man, uden rigtig at gore sig det klart, at vurdere genstandene efter tyngde, haardhedsgrad, overfladekarakter, varmeledningsevne.

Naar man vil kaste en sten, foler man forst, hvordan den er at tage på, vender og drejer den, laggger den til rette indtil man marker, at den ligger rigtigt, saa vejer man den $i$ haanden. Naar man har gjort det tilstrckkelig mange gange, behфver 
man slet ikke røre ved den, for blot man ser paa den, ved man, hvordan den er. Når man betragter en kugleformet genstand, nøjes man ikke med at konstatere dens matematiske form. Ved iagttagelsen er det, som om man beføler den for at opleve dens forskellige egenskaber.

De mange slags kugler og bolde, der bruges til leg og til sport, er matematisk ligedannede, men man erkender dem alligevel som en rakke genstande, med et yderst forskelligt vasen. Alene deres størrelse $i$ forhold til den menneskelige haand giver dem ikke blot en forskellig kvantitet, men også en andret kvalitet. Farven spiller en rolle, men tyngden og styrken er dog meget vigtigere. Den store fodbold, der skal sendes afsted af svare fodboldst $\phi$ vler er vasensforskellig fra den hvide tennisbold, der trakteres med hånden eller med håndens forlangelse. Ketsjeren. ${ }^{9}$

En af prøverne på god arkitektur er, om der bliver levet i den, sådan som arkitekter har tænkt sig. Man må opleve den, mærke hvordan den er formet til løsningen af bestemte opgaver og afstemt efter en tids hele opfattelse og livsrytme. Om arkitekterne foruden sansen for at forene form og funktion i den kunstneriske udformning, har haft fornemmelse for den betydning arkitekturen får for brugerens livssammenhæng.

Der findes monumentale, meget forenklede bygningsvarker, der spiller paa en eneste virkning, for eksempel det haarde og det tunge. Men de fleste bygninger bestaar af kombinationer af haardt og blфdt, af let og tungt, af slapt og spcendt, af mange forskellige slags overflader. Alt dette er elementer $i$ arkitekturen, noget af det arkitekten har at spille på. $O g$ alle disse elementer maa man kunne fornemme, hvis man skal opleve arkitektur. ${ }^{10}$
Akkurat som man ikke læser de enkelte bogstaver i et ord, men modtager en samlet forestilling af det begreb, ordet dækker, således ved man i almindelighed ikke, hvad det er, man sanser, men kun den forestilling, der opstå som resultatet af sansningen.

Vi kommer til at vi ikke kan beskrive oplevelsen af en genstand uden selv at behandle det som et vasen, der har sit eget fysiognomi. For selv den mest pertentlige beskrivelse med opregning af alle synlige egenskaber ville ikke give os noget af det, vi kan føle som vasentligt ved helhedsindtrykket. $^{l l}$

Opgaven er herefter at lære at forstå betydningen af de forestillinger som er resultatet af vores sanselige omgang med virkeligheden. Den proces, hvor forholdet mellem tid, krop, bevægelse og rum, og de dermed forbundne erkendelser forbindes med sproget og andre vidensfelter.

\section{Derfor arven fra Freud}

Vi må gøre os klart, hvad det betyder, at der bag det sproglige plan er skjult et meget mere komplekst praksisplan.

Uden at det har været tilsigtet, slår Steen Eiler Rasmussen i ovennævnte citater toner an, toner der fører os tæt på en personlighed, der aldrig har beskæftiget sig med temaet Idræt og Arkitektur, nemlig psykoanalysens grundlægger Sigmund Freud. Sigmund Freud har fra en hel anden baggrund indgående beskæftiget sig med de iagttagelses- og tænkeprocesser, der knytter an til forholdet mellem de ubevidste tingsforestillinger og de (før)bevidste ordforestillinger. Dermed har han banet vejen for en forskning, der uddyber forbindelsen mellem ubevidst sansning, individuel soci- 
alisering, førbevidste sanseligt funderede forestillinger, konkret virkelighedsoplevelse, og bevidst sprogliggørelse af forskellige former for livssituationer.

Det er vigtigt, at vi i vores intentioner om at forstå produktionen og dannelsen af ubevidste processer, og de sanseligt funderede forestillinger, tilslutter os Freuds banebrydende arbejder.

Jeg tænker her først og fremmest på skrifter såsom »Zur Auffassung der Aphasien « og de metapsykologiske skrifter fra 1912-17. Her bliver konkrete psykologiske erfaringer forbundet med hans driftteoretiske og neurofysiologiske overvejelser, og han udvikler modeller for, hvordan det er muligt at få indsigt $\mathrm{i}$ det ubevidste som et selvstændigt struktureret system.

Det bliver muligt at forstå det ubevidste som et naturligt og socialt resultat af menneskers sameksistens, som er uden for sproget og bevidsthedens domæne til trods for, at det er en kropslig indskrevet figur.

Jeg vil i det følgende præcisere, hvad det er for nogle metapsykologiske indsigter, som jeg mener, det er vigtigt at have kendskab til for at forstå Freuds betydning ikke blot for vores tema idræt og arkitektur, men også for en kritisk indstillet psykoanalytisk Kulturanalyse.

I artiklen »det ubevidste « fra 1915 skildrer Freud det kendskab til det ubevidste, han har fået i forbindelse med behandlingen af de såkaldte narcissistiske psykoneuroser, hvor analysen af nogle særlige affektioner åbnede for en virkelig indsigt $\mathrm{i}$ det gådefulde ubevidste lovmæssigheder.

Freud skriver i sidste afsnit i Vurderingen af det ubevidste i Det ubevidste (1915) Was wir die bewußte Objektvorstellung heißen durften, zerlegt sich uns jetzt in die Wortvorstellung und in die Sachvorstellung, die in der Besetzung, wenn nicht der direkten Sacerinnerungsbilder, doch entfernter und von ihnen abgeleiteter Erinnerungsspuren besteht. Mit einem Male glauben wir nun zu wissen, wodurch sich eine bewußte Vorstellung von einer unbewußten unterscheidet. Die beiden sind nicht, wie wir gemeint haben, verschiedene Niederschriften desselben Inhaltes an verschiedenen psychischen Orten, auch nicht verschiedenene funktionelle Besetzungszustände an denselben Orten, sondern die bewußte Vorstellung umfaßt die Sachvorstellung plus der zugehörigen Wortvorstellung, die unbewußte ist die Sachvorstellung allein. Das System UBW enthält die Sachvorstellung der Objekte, die ersten und eigentlichen Objektbeziehungen; das System Vbw entsteht, indem diese Sachvorstellung durch die Verknüpfung mit den entsprechenden Wortvorstellungen überbesetzt wird. Solche besetzungen, können wir vermuten, sind es, welsche eine höhere psychische Organisation herbeiführen und die Ablösung des Primärvorgangs den im Vbw herschenden Sekundärvorgang ermöglichen. ${ }^{12}$ Individets samspil med sine omgivelser deler sig - set ud fra individets oplevelses- og forestillingsverden - i en tingsforestilling og i en ordforestilling. Når Freud påstår, at tingsforestillingen består i besætningen om ikke af de direkte tingserindringsbilleder, så dog af fjernere liggende erindringsspor, der er afledt af disse, da viser han, at der er en dialektisk og dybtprægende sammenhæng imellem individets forestillingsverden, omgivelserne - og en egendynamisk neurofysiologisk og social udviklingsproces.

De bevidste og ubevidste instanser og dynamikken er i Freuds fremstilling både socialt betinget og fysiologisk indskrevet; objektforestillingerne er rodfæstet som henholdsvis aflejrede erindringsbilleder og erindringsspor i individets krop uden hver- 
ken at være gjort til tingsliggjorte enheder eller underlagt en statisk sproglig orden, (kode). I stedet funderer Freud over, hvad der er den kvalitative forskel imellem en bevidst - og en ubevidst forestilling. Og i den forbindelse udvikler han en kropslig bundet procesorienteret rumlig opfattelse af vekselforholdet mellem systemet »det ubevidste $\ll$ og den bevidste forestilling.

De ubevidste affekter og de dertil hørende driftskæbner består, før end dets indhold er blevet knyttet til en ordforestilling, af en kerne, en grundstruktur af objektbesættelser og oplevelser, der er aflejret som erindringsspor og tingserindringsbilleder. Det sociale og neurofysiologiske vekselspil er som sanselige figurer aflejret i en førsproglig oplevelses- og dannelsesproces, og de er fæstnet i tingserindringsbilleder. De affektbesatte forestillinger producerer billeder og ønsker, der ikke er den enkelte bevidst.

Dette latente og ubevidste mønster er et selvstændigt aflejret betydningslag (»Sinnebene«), en kropslig fæstnet figur bestående og nogle i tid og rum indskrevne spor. Erindringsspor, forestillinger og billeder, som eksisterer uden nødvendigvis at være knyttet til en struktureret eller bevidst ordforestilling. Erindringssporene er indskrevet i legemet, de er ubevidste, aktive og tidsløse, ligegyldigt hvordan den kvalitative relation er imellem tingsforestillingen og den senere erhvervede ordforestilling.

Overgangen fra den primære grundstruktur - af Freud kaldet primærforløbene - og den førbevidste fremtrædende sekundærproces, dvs. syntesen, der fører til den bevidste objektforestilling, sker ved at tingsforestillingen føjes til den dertil hørende ordforestilling. En ubevidst struktur, som er indlejret i kroppen som ordløse praksisfigurer, forbindes med en ordforestilling.

Spørgsmålet lyder nu: Hvad omfatter denne ordforestilling? Hvordan forestiller Freud sig, at denne sprogoperation hænger sammen med de primære objektbesættelser og tingserindringsbilleder.

I sin afhandling »Zur Auffassung der Aphasien « fra 1891, skriver Freud følgende: Das Wort ist also eine complexe, aus der augefürten Bildern bestehende Vorstellungen oder, anderes ausgedrückt, dem Wort entspricht ein verwickelter Associationsvorgang, den die aufgeführten Elemente visueller, akustischer und kinästhetischer Herkunft miteinander eingehen. Die Wortvorstellung erscheint als ein abgeschlossener Vorstellungskomplex, die Objectvorstellung dagegen als ein offener. Die Wortvorstellung ist nicht von allen ihren Bestandteilen, sondern blo $\beta$ vom Klangbild her mit der Objectvorstellung verknüft. Unter den Objectassociationen sind es die visuellen, welche das Objekt in ähnlicher Weise vertreten, wie das Klangbild das Wort vertritt. Die Verbindungen der Wortklangbildes mit anderen Objectassociationen als den visuellen sind nicht eingezeichnet. ${ }^{13}$

Ordet er et knudepunkt, der i en retning forbinder den enkeltes livspraksis såvel processuelt som aktuelt med en anden kompleks forestillingsverden. En kæde af indviklede associationsforl $\varnothing \mathrm{b}$, der er en sammensmeltning af mange sanselige elementer; nemlig visuelle, akustiske, taktile og kinæstetiske indtryk og oplevelser. Ved at benytte Freuds model fra 1891 åbnes for en perspektivrig og flerstrenget dynamisk forståelse for den såkaldte subjekt/objekt relation.

Indførelsen af ovennævnte psykologiske 


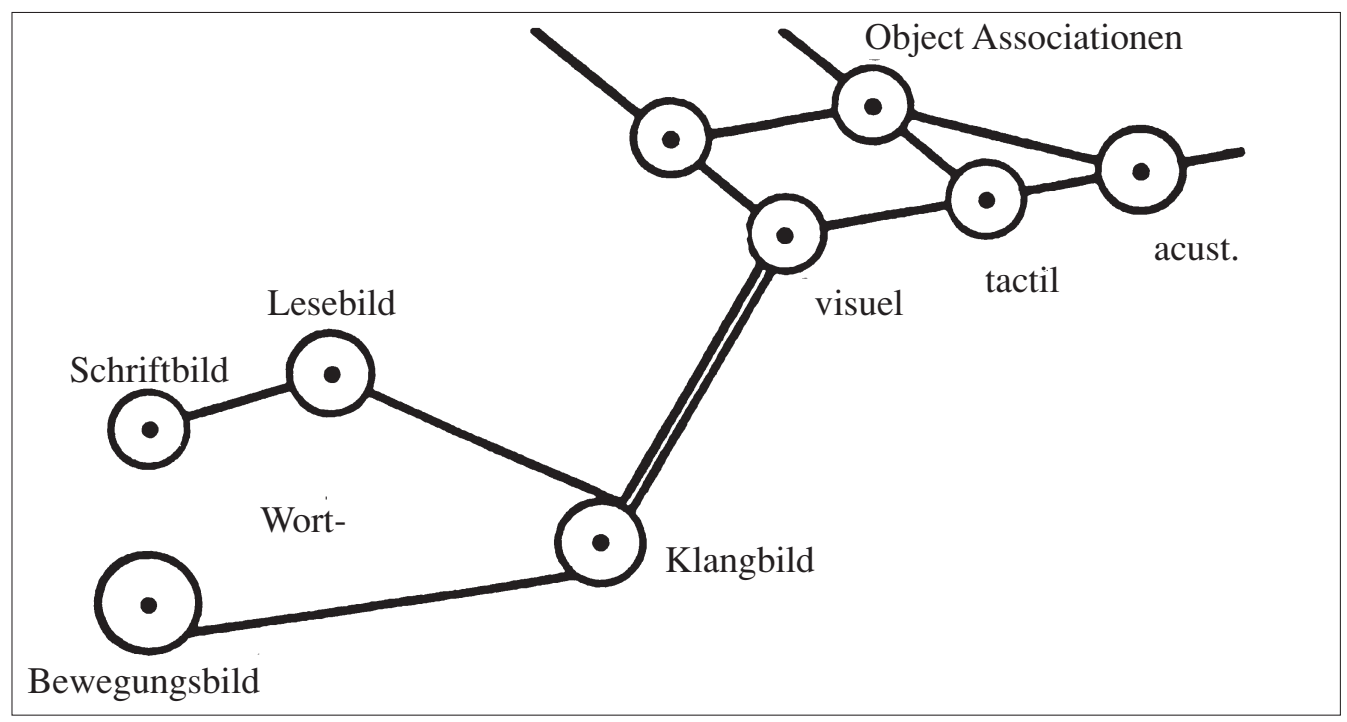

skema over en ordforestilling sprænger sammen med begrebet associationsforløb for en genstandsgørelse af både erkendelsessubjekt og erkendelsesgenstand. For associationsforløbene kan hverken skydes ind under subjektive eller objektive lovmæssigheder. Associationsforl $ø b$, der er sammensat af sanselige modaliteter såsom visuelle, taktile og akustiske objektassociationer, kan ikke logisk eller psykologisk kobles sammen med tingserindringsbillederne fra de kropsligt indskrevne erindringsspor, som handlede det om en række statiske enheder, der kan indordnes under en fastlagt sproglig orden.

Det enkelte individs bevidsthedsdannelsesproces er en syntese imellem flere komplekse systemer, der består af hver sine former for substans og struktur. Det er en forening af kropsligt indskrevne ubevidste og tidsløse figurer, en situativ ordforestilling, og en historisk struktureret figur.

Das Wort erlangt aber seine Bedeutung durch die Verknüpfung mit der >Objectvor- stellung $<$ wenigsten wenn wir unsere Berachtung auf Substantiva beschränken. Die Objectvorstellung selbst ist wiederum ein Associationscomplex aus den verschiedenartigsten visuellen, akustischen, taktilen kinästhetischen und anderen Vorstellungen. Wir entnehmen der Philosophie, daß der Anschein eines >Dinges<, für dessen verschiedenen >Eigenschaften jene Sinneseindrücke sprechen, nur dadurch zustande kommt, daß wir bei der Aufzählung der Sinneseindrücke, die wir von einem Gegenstand erhalten haben, noch die Möglichkeit einer großen Reihe neuer Eindrücke in derselben Associationskette hinzu nehmen (J.S.Mill). Die Objecktvorstellung erscheint uns also nicht als etwas abgeschlossenes, wenngleich der Erweiterung Fähiges erscheint. Die Behauptung, die wir auf Grund der Pathologie der Sprachstörungen nun aufstellen müssen, geht dahin, daß die Wortvorstellung mit ihrem sensiblen Ende (vermittelst der Klangbilder) an die Objectvorstellung geknüpft ist. ${ }^{14}$ 
De psykoanalytiske erfaringer skal laeses i et dobbeltmetaforisk perspektiv

Når Alfred Lorenzer i afsnittet Tiefenhermeneutische Kulturanalyse i Kultur-Analysen. Psychoanalytische Studien zur Kultur påpeger, at begreberne i Freuds metapsykologiske skrifter kan læses dobbeltmetaforisk, da vil han radikalisere, præcisere, uddybe og udvide psykoanalysens socialvidenskabelige perspektiver, uden at opgive dens driftteoretiske og neurofysiologiske fundament. Alfred Lorenzer er uddannet læge og psykoanalytiker, og er den første og eneste mediciner i Tyskland der har været professor på faget sociologi. Alfred Lorenzer har i sin forskning arbejdet på at gøre psykoanalytiske erkendelser brugbare i lyset af en kritisk teori om menneskers samfundsmæssige socialisering.

Dobbeltmetaforisk vil sige at begreberne bliver benyttet dobbelttydigt og interpreteret fra flere erkendelsesteoretiske perspektiver, uden at spændingen mellem fagområderne nivelleres på bekostning af enkeltfaglig erkendelsesinteresser. Det kommer på engang an på at holde fast ved grundlæggende modsætninger inden for psykoanalysens begrebsdannelse, dels at bibeholde fundamentale psykologiske erfaringer, og i et psykoanalystisk regi at åbne for nye kulturkritiske erkendelsesperspektiver.

Grunden til at Alfred Lorenzer tager Freuds tidlige metapsykologiske arbejder op til revision, er at Freud i disse skrifter har leveret et mønstereksempel på, at det er muligt at foretage en transformation af egentlige neurofysiologiske begreber $\mathrm{i}$ sådanne som repræsenterer den dobbeltmetaforiske brug af begreber.

Vi læser igen ud fra dette perspektiv sætningen fra $1915 \ldots$

Den bevidste forestilling omfatter tingsfo- restillingen plus den tilhørende ordforestilling, mens den ubevidste forestilling er tingsforestillingen alene...

Den kan fra det ene perspektiv, læses som om det handler om en ren psykologisk sammenhæng. Set fra et andet perspektiv kan begreberne objektforestilling, sagserindringsbilleder, erindringsspor, besættelsestilstande, de første objektbesættelser osv., fører en henimod den analyse af undersøgelsesplanet, der er neurofysiologisk orienteret.

Styrken ved den dobbeltmetaforiske tilgang til de metapsykologiske begreber er, at spændingen imellem de forskellige erkendelsesfelter ikke elimineres. Derimod opretholdes og udvides begge vidensfelter uden at fagspecifik viden reduceres bort for blindt og uden grundlag at kunne tjene et nyt videnskabeligt perspektiv. Når man betragter begreberne som dobbelttydige knudepunkter, hvor de kan forstås ud fra forskellige erkendelsesperspektiver; ses på den ene side af den dynamiske relation en social sammenhæng. Gennem den psykologiske fremtrædelsesform skimtes en socialvidenskabelig erkendelsesgenstand, hvor subjektive oplevelser bliver psykosocialt erkendt. På den anden side er begreberne entydigt til at sætte i forbindelse med neurofysiologien. Man kan, når de sættes i forbindelse med de ældre tekster, udmærket anbringe dem i et neurofysiologisk rastersystem. Gruppen af objektforestillinger og gruppen af ordforestillinger er delt op i et spektrum af kropsfunktioner, der kan sættes i forbindelse med forskellige sanseorganer. Visuelt, taktil, akustisk, det er receptionsmodaliteter, der fra kropsperiferien bliver ledt til centralnervesystemet, hvor de finder deres oplagring $\mathrm{i}$ indskrevne »hjernearealer«. Det samme gælder ordforestillingerne, som også deles op efter bestemte organiske modaliteter, der har de- 
res plads i sprogcentret. Denne nedskrift af visuelle, taktile og akustiske indtryk sker i engrammer. Disse erindringer er erindringsspor. Det vil sige, at engrammerne i et menneske, er dette menneskes erfaringer. De har en individuel profil.

Freud har været i stand til at vise, at disse erindringsspors erfaringsindhold er funderet i erindringsspor. Han har ikke ligestillet hjernefysiologiske funktioner med psykisk indhold.

Selvom Alfred Lorenzer tilslutter sig Freuds antagelse om at visuelle, taktile og akustiske oplevelser som engrammer indskrives i »erindringsspor «, så vil han med indførelsen af begrebet det sceniske, gøre det klart, at vi ikke oplever verdenen som tingsforestillinger, men at vores daglige oplevelser erfares inden for panoramaet af en levende verden, hvor alle de enkelte erindringsspor er momenter i komplekse situative scenerier. De opleves ikke som afbildninger og isolerede genstande, der så optræder som tingsforestillinger.

Lorenzer udtrykker det således:

Die- socialen - Inhalte der Erinnerung modifizieren die - hirnphysiologisch bestimmbaren-Strukturen des Nervensystems. Und natürlich treten die Erinnerungsspuren zu Objektassoziationen zusammen. So wie die Sinnesqualitäten - visuel, taktil, akustisch - zusammenfließen zur Gestalt einer Objektvorstellung, so fügen sich die veschiedenen in einer Situation wahrgenommenen Objekte zu konkreten Szenen. Aber das ist schon falsch ausgedrückt: Selbstverständlich ist die Szene das unmittelbar Ursprüngliche, die Einzelobjekte treten erst nach und nach aus der Szene heraus, wobei sie in verschiedenen Situationen in der scenischen Gestalt fest umrissene Pole und stabile Figuren bilden. ${ }^{15}$
Med denne drejning, hvor det sceniske kommer til at være det primære i vores måde at opleve omverdenen på, fås en anden tilgang til og opfattelse af, hvorledes livserfaringer bliver til en struktur af erindringsspor.

Alfred Lorenzers antagelse, at verden ikke bliver iagttaget og registreret, som om det var enkeltobjekter, begrunder han med, at mennesket helt fra den tidlige ontogenese oplever forholdet mellem sig selv og omverdenen som et komplekst ensemble af situationsspil. Det, at den primære måde at opleve på er scenisk, bliver tydeligere desto længere man går tilbage i ontogenesen. Individet dannes ifølge Lorenzer i oplevelsesprocesser, hvor rækken af komplekse situationsspil bliver til en personlighedsprofil. Det er først temmelig sent i barnets udvikling, at det bliver muligt for det, skridt for skridt, at iagttage og udgrænse enkelte genstande, som selvstændige objekter.

Kernen i Alfred Lorenzers socialisationsteori er, at de allerførste erfaringer starter i den intrauterinen tid, på et tidspunkt, hvor man faktisk ikke kan tale om erfaringer, men mere om indifferente situationsindtryk. I den første etape i personlighedsdannelsen, drejer det sig om situationsspor. I lang tid er oplevelserne udelelige situationserfaringer. Først lidt efter lidt i vekselspillet med henholdsvis ens scener, og scener der forandrer sig, bliver situationserfaringer differentieret ud i sådanne, som får sin egen skikkelse og struktur. Udgrænsningen af objekter og oplevelsen af ens egen position, som noget kontrært til noget andet, følger meget senere - postnatalt, dvs. efter fødslen.

Med denne opfattelse af organismens udviklingsforl $\varnothing \mathrm{b}$, træder der tre facetter frem i forbindelse med forståelsen af det sceniske. For det første bliver det klart, at 
situationserfaringerne, som en slags aftryk, bliver optaget af det indre ensamble af taktile og akustiske receptorer. Dette sanselige receptionsensamble danner det panorama af reelle indtryk, der så fortættes i engrammer - i en indre scenisk sammenslutning.

Disse situationsengrammer har noget overskridende i sig, da de kan lære at skelne og differentiere mellem den sensomotoriske reception, og reaktionen på denne. Erindringsporene bliver ikke kun til en adfærdsskitse, der er identisk med den ydre bevægelseimpuls, de er på forhånd i sig selv, sensomotoriske. Det kan ses i den kendsgerning, at lyden fra en mus udløser en reaktion $\mathrm{i}$ en kat. Den sensomotoriske erfaringskreds er og bliver en scenisk enhed.

Den grundlæggende sceniske enhed imellem »indenfor og udenfor «, imellem organismen og omverdenen i ontogenesen, er først og fremmest samspillet imellem »fosteret og moderens organisme «. Det er derfor at mor/barn dyaden er vores udgangspunkt, vores grundmodel.

Alfred Lorenzers socialisationsteoretiske videreudvikling af de psykoanalytiske erfaringer, indførelsen af den sceniske forståelse og hans dobbeltmetaforiske tilgang til Freuds tidlige metateoretiske skrifter, må nødvendigvis føre til en korrektur af Freuds begreber. Det gælder begrebet tingsforestilling fra to perspektiver, nemlig som tingsforestilling og tingsforestilling.

Fra det ene perspektiv, mener han, at begrebet tingsforestilling udgrænser de lavere organisalier i hjernen og kobler dermed forbindelsen til refleksbuerne og de perifere lokalisationer. Det medfører, at alle anlæg i de højere centre, de indskrevne og såkaldte indsocialiserede livsudtryk - de nedslag som Freud selv har tænkt på, da han $\mathrm{i}$ forbindelse med tingserindringsbillederne inddrog erindringssporene - , forbli- ver ubeagtede. Alfred Lorenzer vil radikalisere Freud med Freud, og erstatte begrebet forestilling med erindringsspor.

Og det pointeres, at erindringssporene er nedslag fra en herskende livspraksis.

De er ikke kun nedslag, de er også udkast og skitser (lebensentwürfe) i skemaet for en kommende adfærd (jævnfør afsnittene Om idrcet og arkitektur og Derfor arven fra Steen Eiler Rasmussen).

Det andet perspektiv i kritikken af begrebet tingsforestilling ligger i forlængelse af de overvejelser vi var inde på i forbindelse med introduktionen af det sceniske. Vi kan derfor uden at fremføre flere gentagelser erstatte begrebet tingsforestilling med sceniske erindringsspor.

Eben weil sich fundamentalen Erinnerungsspuren in konkreten Situationen niederschlagen, tragen sie die Züge dieser situativen Zufälligkeit an sich. Je mehr der Organismus aber entfaltet wird, und d.h., je komplexer das Gefüge der Engramme wird, desto mehr schlagen diese Zufälligkeiten des täglichen Lebens sich in der lebensgeschichtlich gewordenen Individualität nieder. Rechnet man zu diesen Individualisierungsfaktoren nun noch die Absonderlichkeiten aus der mütterlichen Vermittlung hinzu, deren Einbettung nicht nur in der allgemeinen Sprachgemeinschaft und gesellschaftlichen Praxiszusammenhängen, sondern auch in familialen und mikrokulturrellen Gruppierungen, so schwindet alle Hoffnung auf eine objektivistische Einschätzung der Matrix menschlichen Verhalten. Sie darf freilich keiner subjektivistischen Deutung Platz machen; denn entscheidend bleibt, daß die Persöhnlichkeitsbildung als Einsozialisierung von Verhaltensanläufen in Niederschlägen eines Wechelspiels gesellschaftlicher Formgebung anläuft. Der wichtigste Umstand da- 
bei ist: Die Erinnerungsspuren sind organismische Engramme als Resultate einer Synthese, die diesen Körper selbst bildet. ${ }^{16}$

Det er understregningen af dette vekselspil som beskytter os imod at forsøge at miskende eller undervurdere grundmønsteret i menneskers adfærd, som enten objektivt eller subjektivt bestemt. Vi må respektere den kendsgerning, at den samfundsmæssige indflydelse på den ene side, og organismens arvegenetiske muligheder på den anden, bliver bundet sammen og realiseret $\mathrm{i}$ et indbyrdes vekselspil.

Freud hatte mit der Trieblehre aufgedeckt, das alles Erleben einen sinnlich-körperlichen kern hat. Aber die Erkenntnis der Natürlichkeit des Erlebens diente zugleich dazu, die Beweggrunde der Persöhnlichkeit ins Urzeitliche, Geschichtslose zu verschieben. Unsere Aufgabe ist es nun, den schleier dieser Mystifikation zu durchdringen, um den Zusammenhang von Triebstruktur und Erleben als Leitlinie einer Theorie der objektiv bedingten Subjektbildung vorzuweisen, als Leitlinie einer Theorie, die von gesellschaftlich hergestellten Triebstruktur die Beziehungen zu den objektiven Bedingungen der biologischen Natur ebenso wie zu den objektiven Bedingungen der gesellschaftlichen Prozesse aufzudecken hat. $^{17}$

Hvis man i sin betragtning af dette vekselspil, kun udefra ser på de mange tilfældige situationer, som virker ind på et sådan vekselspil, da kan man komme til den antagelse, at ethvert individs kropsspil helt og holdent er objektivt bestemt. Med inddragelsen af den sceniske model ved vi, at individet på forhånd, på trods af de objektive betingelser, besidder sin egen individuelle prægning. Her er det vigtigt for vores te- matik endnu engang at slå fast at kropsfigurerne er et livsregulerende Sinnsystem, som mangler alle de kendetegn, der er karakteristisk for »sproget«, nemlig den grammatiske inddeling og den logiske orden.

Det ubevidste er ikke sprogligt, det er et symbolsk »Sinnsystem «, som eksisterer op imod og måske i opposition til individets sproglige foreskrifter og symbolske orienteringsramme. Det ubevidste Sinnsystem er en i sig selv hvilende struktur, en matrix, der er vokset ud af en konkret vekselproces, det er nedskriften og resultatet af en helt igennem speciel og særegen ontogenetisk udvikling. Men det er alligevel en systematisk udvikling, fordi lige fra det første moment i livshistorien følger et erindringsspor et andet, de er alle forbundet med hinanden som én organisme. Det er en menings- og betydningsfuld organisme, fordi engrammerne er resultatet af et allerede forløbet sammenspil, et hvor det sociale nedslag resulterer i et livsudkast, en skitse som også er iscenesættelsen af et kommende socialt sammenspil. Det er potentielle adfærdsskitser - kommende interaktionsformer.

Lorenzer udtrykker det således:

Der begriff, Gefüge von Praxisfiguren spielt auffolgende Besonderheiten an: Das Wechselspiel, aus dem die Erinnerungsspuren (Interaktionformen) hervorgehen, ist ja nichts anderes als ein Austausch von Gesten, Körperbewegung, sozial geformten, sozial relevanten Körpervorgängen; es ist >Praxis<. Jede Interaktionsform ist Teil dieser Praxis und daher weiter, umfassender als die Sprache, denn das Gesamtgebiet der Praxis ist zwar teils den Sprachregeln gefügig, teils widerständig und widerstrebend oder aber ein Bereich des Utopi- 
sch-noch-nicht-Bewußten, d.h. des noch nicht in Sprache eingefaßten menschlichen Handelns. ${ }^{18}$

Problemet er nu at vise, hvorledes forbindes dette primære Sinnsystem med sproget, hvordan ser den proces ud, og hvad indebærer det for vores tema?

\section{Forholdet mellem sprog og krop}

I min fremstilling af, hvordan det primære »Sinnsystem《 knyttes til sproget vil jeg støtte mig til Alfred Lorenzers interpretation af Freud. Det er vigtigere at kunne sætte af fra en socialisationsteoretisk koncept, der kan bruges som teoretisk grundlag for vores tema frem for at fortabe sig $\mathrm{i}$ en Freud eksegese.

Når vi stiller spørgsmålet: Hvorledes forbinder dette primære »Sinnsystem « sig med sproget, så gør vi selvfølgelig brug af de indsigter og nuancer, som er vundet med den sceniske forståelse. Vi opretholder også i denne forbindelse vores socialisationsteoretiske ansats og den dobbeltmetaforiske perspektivering af psykoanalysens socialvidenskabelige indsigter og neurofysiologiske fundament, når vi endnu engang kredser om tesen:

Den bevidste forestilling omfatter tingsforestillingen plus den tilhørende ordforestilling, mens den ubevidste forestilling er tingsforestillingen alene...

og også denne gang sætter vi den i forbindelse med Freud teksten fra 1891.

Wir wollen nun nachsehen, welcher Annahmen wir für die Erklärung der Sprachstörungen auf Grund eines solchen Aufbaues des Sprachapparates bedürfen, mit an- deren Worten, was uns das Studium der Sprachstörungen für die Funktion dieses Apparates lehrt. Dabei wollen wir die psychologische und die anatomische Seite des Gegenstandes möchlichst voneinander trennen.

Für die Psychologie ist die Einheit der Sprachfunktion das ,Wort<, eine komplexe Vorstellung, die sich als zusammengesetzt aus akustischen, visuellen und kinästhetischen Elemente erweist. Die Kenntnis dieser Zusammensetzung verdanken wir der Pathologie, welche uns zeigt, daß bei organischen Läsionen im Sprachappararte eine Zerlegung der Rede nach dieser Zusammensetzung eintritt. Wir werden so darauf vorbereitet, dass der Wegfall eines dieser Elemente der Wortvorstellung sich als das wesentlichste Kennzeichen erwiesen wird, welches uns auf die Lokalisation der Erkrankung zu schließen gestattet. ${ }^{19}$

I sin model til belysning af sprogfunktioner og i hans overvejelser over opbygningen af sprogapparatet skelner Freud også imellem genstandsfeltets psykologiske og anatomiske side. Derved bliver det også i denne sammenhæng muligt at se såvel den psykologiske som den anatomiske side af undersøgelsesgenstanden, som fremtrædelsen af et funktionskompleks, der er udeleligt og sammensat at akustiske, visuelle og kinæstetiske elementer. Disse »elementer « er hjernestrukturer. Ordforestillingens bestanddele er identiske med celebrale strukturer og processer. Dvs. sprogbevægelsesforestillingen f.eks. svarer til centipetale fornemmelser fra sprogorganer.

Det kommer ikke kun an på at betone, at det sjælelige har et materielt substrakt, men også at gøre det klart, at psykiske enheder opstår som en forening af associationer og neurofysiologiske forløb ordklangbilleder, ordinnovationsfølelser og sprog- 
bevægelses-forestillinger. Disse begreber henviser på en gang til psykiske indhold og nervefunktioner.

Man führt gewöhnlich vier Bestandteile der Wortvorstellung an: das >Klangsbild<, das ,Visuelle Buchstabenbild und das ,Schreibbewegungsbild<. Diese Zusammensetzung erscheint aber komplizierter, wenn man auf den wahrscheinlichen Assoziationsvorgang bei den einzelnen Sprachverrichtungen eingeht:

(I) Wir lernen sprechen indem wir ein ,Wortklangbild< mit einem ,Wortinnervationsgefühl assoziieren. Wenn wir gesprochen haben, sind wir in den Besitz einer 'Sprachbewegungsvorstellung< (zentripale Emfindungen von den Sprachorganen) gelangt, so daß das >Wort für uns motorisch dobbeltbestimmt ist. ${ }^{20}$

I begrebet ordklangbilleder antydes det sensoriske, og i begrebet sprogbevægelsesforestilling, den motoriske andel i et sensomotorisk sammenspil. Vi har et kredsløb for os, som præcist svarer til det, vi har fundet ved erindringssporene, nemlig den sensomotoriske interaktionsform.

Det bekræftes i Freuds beskrivelse:

Wir lernen lesen, indem wir Nacheinander der Wortinnovations- und Wortbewegungsvorstellungen, die wir beim Sprechen der einzelnen Buchstaben erhalten, nach gewissen Regeln verknüpfen, so daß neue motorische Wortvorstellungen entstehen. Sobald letztere ausgesprochen sind, entdecken wir nach dem Klangbild dieser neuen Wortvorstellungen, daß uns beide Wortbewegungs- und Wortklangbilder, die wir so erhalten haben, längst bekannt und mit den wärend des Sprechens gebrachten identisch sind. Nun assoziieren wir diesen buchstabierend gewonnenen Sprachbil- dern die Bedeutung, welche den primären Wortklängen zukam. Wir lesen jetzt mit Verständnis. ${ }^{21}$

Det er et selvstændigt kredsløb, som her bliver skitseret. Høren og talen danner en cirkel, der går fra $\emptyset$ ret og sprogcentret til strubehovedet og tilbage til øret igen. Dette kredsløb kan enten eksistere uden impulser udefra, eller ord fra andre mennesker, kan udefra kile sig ind i kredsløbet. Når kredsen slutter sig solipistisk så taler eller tænker individet for sig selv.

I begge tilfælde, ved den ydre (offentlige) og den indre (private) talen, sker der det samme, som vi kan iagttage, når mennesker handler. En allerede eksisterende adfærdsformel dvs. interaktionsform bliver omsat i en interaktion. Mønsteret vi kender går igen; Interaktion - Interaktionsform. Resultatet af interaktionen går som ny eller modificeret interaktionsform igen i kæden af interaktionsformer. Lige som strukturerne dannes i de samlede organiske kropsfornemmelser og kropsbevægelser, sådan dannes også denne specielle »lille cirkel«, kredsløbsbevægelsen fra høren og talen: Ordinnovationsfølelsen - sprogbevægelsesforestillingen. 2. klangbillede. Kredsbevægelsens egenart mellem adfærdsmønster og adfærd - interaktionsform og interaktion i høre - tale kredsen, bliver også fremhævet af Freud

Es ist anzunehmen, daß wir die einzelnen Sprachfunktionen auch späterhin auf denselben Assoziationswegen ausüben, auf welchen wir sie erlernt haben. Es mögen dabei Abkürzungen und Vertretrugen stattfinden, aber es ist nicht immer leicht zu sagen, von welcher Natur. Die Bedeutung derselben wird noch durch die Bemerkung herabgesetzt, daß in Fällen von organisher Läsion der Sprachapparat wahrscheinlich 
als Ganzes einigermaßen geschädigt und zur Rückkehr zu den primären, gesicherten und umständlicheren Assoziationsweisen genötigt sein wird. ${ }^{22}$

Overført til, og set i lyset af en socialisationspraksis, må forbindelsen af interaktionsfigurer og sproget i sprogindlæringssituationen spænde over en dialektisk modsætning.

Ligegyldigt, hvor meget vi må gå ud fra, at hvert enkelt ord, som en del af et objektivt sprogsystem, har et objektivt indhold, når det bliver formidlet til barnet, så må det også gælde: Lydkomplekset (ord, tegn) modtager i sprogindføringen først sit indhold i det $\varnothing$ jeblik, barnet bliver inddraget i en situation, hvor $»$ ordforestillingen $\ll \mathbf{o g}$ tingsforestillingen føjes sammen.

Udvider vi Freuds tese om, at den bevidste forestilling omfatter tingsforestilling plus den dertil hørende ordforestilling med Alfred Lorenzers korrektur af begrebet tingsforestilling til scenisk erindringsspor/ interaktionsform, bliver det klart, at ordet først får et indhold, en betydning, når det kobles sammen med et individs indsocialiserede livspraksis. Indtil da forløber interaktionsspillet ubevidst, nemlig som pirrings - reaktionscirkel.(Jævnfør Steen Eilser Rasmussens bemærkning i

Om at opleve arkitektur. En mand der sad på Wodgwoods fabrikker og lavede hanke, sagde, at det var saadant et dejligt arbejde. Det var en nydelse at bøje den svajede hank ind mod den pareformede kop. Han kendte ingen ord for mere komplicerede fornemmelser. Ellers ville han maaske havde sagt, at han godt kunne lide det rytmiske $i$ hanken og koppen. Men selv om han ikke kunne udtrykke det, havde han i hvert fald oplevet det.)

Den enkeltes konkrete livspraksis bliver bevidst, når pirringsrings - reaktionscirk- len er føjet sammen med høre - tale cirklen. Ordet bliver livshistorisk konkret, når det associeres sammen med en praksisfigur.

Paralleliseringen af begge cirkler og sammensmeltningen af ord og interaktionsform i ontogenesen sker som sprogindføring i livssituationen, når et bestemt adfærdsmønster i et situationsspil, bliver benævnt med et navn. Det klassiske eksempel er barnets respons på det moment, hvor moderen henvender sig til barnet, og ordet mor bliver hørt og taget til sig af barnet, der så bagefter selv benævner livssituationen med ordet mor.

Forbindelsen af interaktionsform og ord er ikke andet en symboldannelse. Et livspraktisk forløb, en håndbevægelse, en situation, f.eks, en afsked bliver forsynet med ordet vinken. Det vil på den anden side også sige, at håndbevægelsen får en plads $\mathrm{i}$ systemet af lydassociationer, dem som vi nævner - sprog. Et bestemt lydkompleks, ordet, vinken, repræsenterer fra nu af og i fremtiden denne håndbevægelse, som kan henføres til en bestemt situation. Tre andele danner en enhed - kroppen, situationen og ordet. Sprogfigur og Praksisfigur danner tilsammen symbolet.

Ord og interaktionsform danner sprogsymboler, det er derfor, at Alfred Lorenzer har kaldt dette symbolkompleks - sprogsymbolske interaktionsformer. Er ordkompleks og interaktionsformerene føjet sammen i en sprogsymbolsk enhed, så kan man ved hjælp af sproget, »råde « over praksis.

Når praksisfigurerne fra det store oplevelses- og adfærdskredsløb så at sige er transformeret og forlagt til det lille kredsløb (det lukkede sprogforløb), kan individet bestemme over sin praksis i form af overvejede og selviscenesatte prøvehandlinger. Sproget kan intervenere i forhold til praksis, fordi ordene er en del af et sym- 
bolsystem, der er opstået som historiske og kollektive praksiserfaringer. Det er i den betydning, at man kan sige at sproget er praksisregulerende. Alligevel vil al praksis, som vi udførligt har diskuteret det, så at sige på forhånd have sin egen ontogenetiske historie bag sig. Enhver situation bærer sit eget situative element ind i handlingsfeltet. Den individuelle forhistorie sådan, som den kommer til udtryk i de figurer vi har beskrevet, trænger ind i sproget og giver sprogbetydningen dets objektive - subjektive karakter.

Det at sprog råder over praksis, nævner vi en aktiv vending, »at handle udadrettet «, »iagttage med bevidsthed «. I den indre omgang med os selv, benævner vi det reflektion, bevidst fornemmelse eller følelse.

Inden vi indlader os på problemet omkring desymbolisering og resymbolisering, vil jeg endnu engang ridse nogle af de punkter op, hvor vi med Alfred Lorenzers koncept overskrider og udvider Freuds begreber og udsigelsesfelter. Lad os igen tage udgangspunkt i begreberne scene og praksis, som kritiske bestemmelser til Freuds $»$ tingsforestilling $«$.

Ved de ubevidste interaktionsformer fandt vi, at den »sceniske karakter «, er et konstitutionstræk. Tilbagekoblingen, Rygkoblingen, til afasielæren understreger dette på tre områder. Det er ikke kun »tingsforestillingen «, der viser sig selv som et ensamble af sanseindtryk baseret på kropslige receptorer. Med ordforestillingen og med bevagelsesbilleder, ordklangbilleder etc. forholder det sig ikke anderledes. Frem for alt tjener dette kropsbunde ensamble ikke til andet end at optage situationsbillederne i deres fuldstændige sceniske fylde og sanselige umiddelbarhed. I det vi på den ene side ikke kun forstår de sceniske indtryk, som en bearbejdelse af en reel omverden via et apparat, men samtidig også opfatter denne forarbejdning som bestemte forventningsfigurer, indskrevne interaktionsformer, da bliver det klart, at hverken tingsforestillingen eller de sceniske indtryk er »ting «, som vi optager i os for at besidde dem, men meget mere optræder som praksisfigurer. Den tingsforestilling som knyttes til ordforestillingen er praksisfigurer, nedslag af realerfaringer, altså en interaktionsform. Når vi udtaler et ord, råder vi kun over en ting for så vidt, at vi kunstigt har opdelt og udledt det fra scener, dvs. abstraheret fra en konkret praksis. Måske er det nyttigt et øjeblik at holde inde for med et par stikord at gøre det klart i hvilket omfang begrebet, tingsforestilling, er udvidet.

For det første er der sket en udvidelse rent rumligt. For tingsforestillingen er oprindeligt scener som først i en senere operation i forbindelse med sproget bliver udlagt som, og fremstillet som en mængde objekter $»$ ting $«$.

De »sceniske erfaringer « er meget mere end »forestillinger «, de er sanselige enheder, der forbinder et differentieret ensamble af forskellige sanseindtryk til et kompleks.

Disse sceniske erfaringskomplekser er underlagt vidt forskellige iagttagelsesmåder. De gennemløber sanselige registreringer fra vidt forskellige erfaringsplaner, fra kropsoverfladen over oplevelsens forskellige relæstationer helt ind til det centrale nervesystem med det resultat at iagttagelsesindholdet bliver tillagt en emotionel resonans, og enkeltiagttagelsen får til slut sin plads i helhedsoplevelsen. Komplekset og sceniske oplevelser eksisterer ikke kun på receptionsiden. De er også sensomotoriske helheder, dvs. de er dele af menneskers praksis, praksisudkast, praksisfigurer. Det, at de sanselige praksisfigurer har en scenisk gestalt, får en prægende betydning for »ordforestillingen $\ll$. 
Netop fordi den sammenhæng, som sprogfiguren relaterer sig til er en scenisk, må den svare til at et scenisk udfoldet sprogbillede - en sætning. De sprogsymbolske interaktionsformers sprogandele består altså af »sætninger «. Freuds ordforestillinger er i følge Alfred Lorenzers opfattelse, sætninger, grundsymbolet Mama (mor) er et enordssætning.

I bogen Til begrundelse af en materialistisk socialisationsteori har Lorenzer udførligt fremstillet, at lydkomplekset mama allerførst er et signal, og først i det gentagne ord bliver accepteret af moderen, bliver det en del af en sprogsymbolsk sitituationsform. Hertil må selvfølgelig træde den omstændighed, at opbygningen af sproget må svare til sprognettet. Først når et lydkompleks har opnået en plausibel plads i sprogtegn sammenhængen, er det trådt $\mathrm{i}$ forbindelse med sprogets syntaktiske og semantiske væsen. Da står den sceniske praksisfigur overfor et ligeværdigt og udfoldet sprogbillede. På det tidspunkt antager sprogfiguren dens karakter og bliver en sproglig udfoldet »scenisk repræsentant $«$.

Det er ikke en selvfølge at alle sceniske erfaringer bliver omsat fra »den store« til den »lille cirkel«, dvs. at enkeltoplevelsen finder en plads i helhedsopfattelsen og dermed bliver bevidst, som sprogsymbolsk interaktionsform. Ikke alle menneskers livsudkast og potentielle praksisfigurer bliver til bevidste objektforestillinger. Der skal være plads til dem, for at de kan optages i bevidstheden. Processen skal tillades, og det er ikke udelukket, at et bredt udsnit af livspraktiske figurer udelukkes fra eller forbydes af det herskende normsystem. Det er heller ikke givet, at når en interaktionsform er blevet optaget i et scenisk udfoldet sprogbillede, at det ikke senere bliver stødt ud igen. Det kan være, at det ønskede lydkompleks ikke bliver accepteret, hverken af den sprogindførende person (moderen), eller det overhovedet finder en plausibel plads i sprogtegn sammenhængen, som sprogsymbolsk interaktionsform. Den sceniske praksisfigur kan så at sige blive stødt ud af sprogfiguren.

Den forestilling, der ikke er udtrykt $i$ ord, eller den psykiske akt, der ikke er overbesat, bliver derefter tilbage $i$ det ubv som fortrangt.

Sætningen - den ubevidste forestilling er tingsforestillingen alene - denne formel præciserer $i$ en eneste halvsætning fortrængningsprocessen, som en genopløsning af symbolenheden. Det fra ordet adskilte interaktionssystem bliver igen til en ubevidst interaktionsform. Ordet taber sin forbindelse til en sanselig praksis, og bliver emotionsløst - til et tegn. Det interaktionsengram som igen er blevet ubevidst, taber alle de egenskaber som det havde vundet, da det var forbundet med ord der havde en plads i systemet af sproglige betydninger.

Når ordet mister sin plads i systemet af sproglige betydninger, taber individets sporadisk nogle egenskaber, nemlig evnen til i bestemte situationer at reflektere over sit adfærdsmønster. Det er ikke længere i stand til bevidst at gribe ind i et adfærdskredsløb med selvstændige prøvehandlinger. Individet får svært ved at orientere sig og handle realistisk i visse livssituationer.

I stedet indtræder igen en ubevidste situationstvang med alle sine rettigheder. Akkurat som i en pirrings - reaktionscirkel hos andre levevæsener end mennesket, hvor der i bestemte livssituationer mobiliseres en fikseret »instinktiv« adfærdsformel. Det er også på denne måde at en interaktionsform sætter sig igennem som et symtom, der kan være så forvrænget, at det fortrængte interaktionsudkast ikke kan genkendes i sin sande og oprindelige skik- 
kelse. Det som fortrængningen er rettet imod, er interaktionsformer, der kolliderer med kollektivets normer og værdier, de bliver derfor ikke anerkendt som handlingsudkast og tankemønstre, og de får derfor ikke lov til at sætte sig igennem som symbolske interaktionsformer. De forbliver ubevidst, de er ikke til at genkende, hverken i tanken eller i handlen, men de er alligevel uimodståeligt virksomme i deres forvanskede fremtrædelsesform. De desymboliserede sprogtegn derimod får en anden skæbne. De bliver i bevidstheden og viser sig ovenikøbet at være særdeles lette at manipulere med fordi de er befriet for bindingen til praksisudkastene, de optræder som den kalkulerende tænkning, og i den form for kold rationalistisk handlen, som har tabt enhver forbindelse til de oprindelige livskvaliteter.

\section{Dannelsen af sanselige umiddelbare symboler}

I det foregående har vi hovedsageligt beskæftiget os med de ubevidste interaktionsformer og dannelsen af sprogsymbolske interaktionsformer. Vi har kort behandlet dynamikkerne omkring fortrængning, desymbolisering og genkomsten af det fortrængte. I den forbindelse har vi sprunget et led over, som er særdeles vigtig for at kunne forstå idrættens og arkitekturens betydning som socialisationsinstitution, nemlig dannelsen af de såkaldte sanselige umiddelbare symboler. De eksisterer i virkeligheden ved siden af og udenfor sprogets domæne, men har på en anden vis end sproget - som sanselige symbolske interaktionsformer - stor betydning som et personlighedsstiftende symbolsystem.

Freud har i sine tidlige metateoriske skrifter ikke betragtet de sanselige umiddelbare symboler. Han har heller ikke for- søgt at belyse materialitetsformernes betydning for dannelsen af ubevidste kropsfigurer, og de former for selverfaring og adfærdsmønstre, som opstår på tværs af sprogindlæringen.

Alligevel har han $\mathrm{i}$ et senere arbejde »Jenseits des Lustprinzips" givet en beskrivelse af et barns leg med en garnrulle, der må tages alvorligt op til overvejelse. Freuds iagttagelser af garnrullens betydning for barnets iscenesættelse af dets sociale situation nøjes ikke med at betone den indflydelse de sanselige umiddelbare symboler har for barnets socialitations- og selvrealiseringsproces, de åbner i forbindelse med Lorenzers interpretation for en større forståelse for de sanselige symbolske interaktionsformers betydning for menneskers personlighedudvikling.

Das Kind war in seiner intellektuellen Entwicklung keineswegs voreilig, es sprach mit anderthalb Jahren erst wenige verständliche Worte und Verfügte außerdem über mehrere bedeutungsvolle Laute, die von der Umgebung verstanden wurden. Aber es war in gutem Rapport mit den Eltern und dem einzigen Dienstmädchen und wurde wegen seines anständigen< Charakters gelobt. Es störte die Eltern nicht zur Nachtzeit, befolgte gewissenhaft die Verbote, manche Gegenstände zu berühren und gewisse Räume zu gehen, und vor allem anderen, es weinte nicht, wenn die Mutter es für Stunden verließ, obwohl es dieser Mutter zärtlich anhing, die das Kind nicht nur selbst genährt, sondern auch ohne jede fremde Beihilfe geplegt und betreut hatte. Dieses brave Kind zeigte nun die gelegentlich störende Gewohnheit, alle kleinen Gegenstände, deren es habhaft wurde, weit weg von sich in eine Zimmerecke, unter ein Bett usw. zu schleudern, so daß das Zusammensuchen seines Spielzeu- 
ges oft keine leichte Arbeit war. Dabei brachte es mit dem Ausdruck von Interesse und Befriedigung ein lautes, langgezogenes o-o-o-o hervor, das nach dem übereinstimmenden Urteil der Mutter und des Beobachters keine Interjektion war, sondern $>$ Fort $<$ bedeutete. Ich merkte endlich, daß das ein Spiel sei, und daß das Kind alle seine Spielsachen nur dazu benützte, mit ihnen >Fortsein< zu spielen. Eines Tages machte ich dann die Beobachtung, die meine Auffassung bestätigte. Das Kind hatte ein Holzspule, die mit einem Bindfaden umwickelt war. Es fiel ihm nie ein, sie zum Beispil am Boden hinter sich herzuziehen, also Wagen mit ihr zu spielen, sondern es warf die am Faden gestaltene Spule mit großem Geschick über den Rand seines verhängten Bettchens, so daß sie darin verschwand, sagte dazu sein bedeutungsvolles o-o-o-o und zog dann die Spule am Faden wieder aus dem Bett heraus, begrüßte aber deren Erscheinen jetzt mit einem freudigen >Da<. Das war altso das komplette Spiel, Verschwinden und Wiederkommen, wovon man zumeist nur den ersten Akt zu sehen bekam, und dieser wurde für sich allein unermüdlich als Spiel wiederholt, obwohl die größere Lust unzweifelhaft dem Zweiten Akt anhing. ${ }^{23}$

Freud så i barnets lege med garnrullen dets iscenesættelse af moderens kommen og gåen. Spillet med garnrullen er et skridt fra passivitet til aktivitet fra at være domineret af moderen, til at udøve selvstændige aktiviteter.

Når vi inddrager Freuds iagttagelser i vores socialisationsteoretiske perspektiv, bliver det klart, at vi er vidne til barnets første symboldannelser.

Den ene scene, den med moderen, bliver repræsenteret af en anden scene, legen med garnrullen. Strukturuanalystisk betragtet vil det sige, at der bliver dannet et symbol idet en scene bliver knyttet med en anden. Den ene scene betyder den anden, for den ene scene er en udlægning af den. Tilsammen og kun tilsammen, danner de et symbol.

Kaster man et blik på de sociale hændelser, så finder man der en ikke mindre entydig difference, der på en højst interessant måde, meningsmæssigt, viser sig som en modsætningsfuld prægning. Ved sprogsymbolerne bliver livssituationen optaget på to forskellige måder. Det er jo præcist deri at sprogets donationsværdi beror.

Når moderen viser barnet en genstand og nævner det ved navn, bliver den samme scene af barnet i dobbelt forstand iagttaget med forskellige midler. Ved garnrullespillet derimod ser det to helt og fuldstændigt forskellige scener, der begge gange bliver iagttaget og registreret umiddelbart i en livspraktisk sammenhæng. Das tertium comparationis ligger i strukturligheden. Nemlig, moderens gåen væk og kommen igen, og at garnrullen bliver smidt væk og bliver fundet. Den dukker op igen.

Symbolet er en forbindelse af to scener, den strukturelle egenart som er særegen for garnrullespillet, deler det med sprogsymbolerne. I sprogsymbolerne bliver der, som vi allerede har drøftet det, to forløb bundet sammen: en adfærdsscene med en ordforestilling eller mere kropsnært, en sensomotorisk sammensat organisk erfarbar scene, med en figur fra tale - høre - feltet.

Neurofysiologisk er det muligt entydigt at bestemme denne forskel. Medens der ved sprogsymbolerne bliver lagt scener sammen, der $i$ to henseender er af forskellig art - nemlig oplevelsesformer, der aflejres i forskellige steder i hjernen i de sensomotoriske arealer og i »sprogcentre«. Det er anderledes med symboler som garnrullespillet, dem kalder vi, for at kunne 
skelne dem fra sprogsymbolerne, sanselige symbolske interaktionsformer. De er scener af samme art, fordi de bliver forbundet med hinanden som nedlagte engrammer i cerebral registraten

De konsekvenser der opstår på grund af de forskellige måder vi optager oplevelser på er mangfoldige. Der er de praksisfigurer, som bliver sammensat, og danner sprogsymbolske interaktionsformer. De opnår på èn gang tilgang til sprogets uudtømmelige instrumentalitet, og er samtidig underlagt sprogets logiske konsistenstvang og det reglement, der følger med de normbestemte motiver.

Rækkevidden af de sanselige symbolske interaktionsformer er anderledes, de griber akkurart så vidt, som begge andele af den livspraktiske betydning rækker. I eksemplet med garnrullen viser den ene pol af symbolet, moderen, sig gennem en overordentlig omfattende betydningsfuldhed. Den anden, garnrullen, er kendetegnet ved at være indflydelsesrig $i$ et mere begrænset omfang.

Overgangsobjekterne giver den mulighed, at det kan lade sig gøre at veksle imellem begge poler. Fra den begrænsede til den mere komplekse og righoldige. Betydningsfeltet mor hæfter sig da til det mere begrænsede betydningsfelt teddybjørn, garnrulle osv. Det kan lade sig gøre at erstatte den ene med den anden, og gribe tilbage til den andens betydnings righoldighed og dybde.

Betydningen af de sanselige, symbolske interaktionsformer bliver begrænset i omkredsen af de to livspraksisser, som bliver aktualiseret. Derfor fører disse symboler et større egetliv i de til enhver tid gældende praksisnicher end de sprogsymbolske interaktionsformer, som er fanget af den sociokulturelle koncensustvang.

Også drømmebillederne udnyttes og det $\emptyset$ gede spillerum, som de har hører således også til klassen af sanselige symbolske interaktionsformer. Stiller man »overgangsobjekterne« op ved siden af drømmebillederne så bliver yderligere to egenskaber ved de sanselige symbolske interaktionsformer anskueliggjort. Overgangsobjekterne er, som det tydelige fremgår af eksemplet med garnrullen lettere at håndtere, hvorimod det ikke er muligt at kontrollere moderen, som barnet kun i begrænset omfang kan disponere over.

Drømmebillederne derimod præsenterer det andet fortrin, nemlig en ideel tilgængelighed. Drømmene er via regia til tydningen af det ubevidste, og som sådan bringer de det usigelige ind i billedet.

\section{Socialisationsteoretiske konsekvenser}

For at forstå den betydning ovennævnte erkendelser har for menneskers samfundsmæssigt betingede socialiserings- og symboliseringsprocesser, vil jeg i korte træk fremlægge grundelementerne i Alfred Lorenzers socialisationsteoretiske koncept. Ifølge den foregår dannelsen af menneskers personlighedsstruktur i tre trin. I grove træk, kort ridset op, er de tre trin delt således op.

Det første trin »grundtrinet «, det intrauterine stadium, starter så snart fosteret optræder som selvstændig organisme i moderens mave. Da opstår der et vekselforhold mellem mor og barn, der som liv i liv udvikler et pirrings- og reaktionsmønster som i forbindelse med biologiske processer og kropsbestemte bevægelsesfigurer indlejres som et struktureret mønster i det kommende menneske.

Pirrings og reaktionsprocessen, indlejringerne af vekselspillet imellem mor og barn er ikke kun en stofvekselproces, men udvikler sig mere og mere til at blive et ud- 
foldet og differentieret spil af interaktioner. Her i dette allerførste trin i personlighedsdannelsen udvikles adfærdsformler, der indskrives i kroppen på det vordende menneske. Fordi barnets udvikling fra aller første færd udfoldes i et socialt og intimt vekselspil med den moderlige organisme, former dette vekselspil opbygningen af embryoen - den føtale psykofysiske organisme. Disse elementære former i kropsprogrammet er interaktionsformerne eller anderledes udtrykt, interaktionsmønsteret.

Det er vigtigt i denne forbindelse at betone, at disse interaktionsmønstre, der er opstået som nedslag og udkast imellem mor og barn, er bestemmende for den videre kropsudvikling og determinerer al videre opførsel og adfærd. Dannelsen af disse fysiologiske grundelementer, udkastene for det kommende menneskes adfærdsmønstre, følger helt fra begyndelsen hele tiden mønsteret. Interaktion - Interaktionsengram - Interaktion. Engram betyder ikke andet end at sammenspillet bliver holdt fast i spor, der er bestemmende for adfærden. De enkelte interaktionsengrammer føjer sig sammen til en struktur af interaktionsengrammer, som er vokset sammen på kryds og tværs, over og under og ved siden af hinanden. Denne struktur af interaktionsengrammer er det fysiologiske grundlag for den psykiske struktur.

Vekselspillet imellem mor og barn må anskues i flere dimensioner end den psykofysiske. Der er flere perspektiver i mor/ barn dyaden, blandt andet et psyko/socialt. De to aspekter i socialisationsprocessen kan ikke adskilles, men heller ikke betragtes og beskrives samtidigt. Netop fordi den ene er en psykofysisk og den anden en psykosocial proces. Det psykofysiske og det psykosociale kan, som vist, ikke begribes i den samme videnskabelige operation. Den kan heller ikke begribes med de sam- me videnskabelige kategorier og begreber. Det er to genstandsfelter der krydser hinanden i det samme menneske, som ikke kan forstås isoleret og alene ud fra hverken en psykofysisk eller psykosocial betragtningsmåde. Hvis vi betragter vekselspillet imellem mor og barn i det psykosociale perspektiv, betyder begrebet interaktion opgøret imellem barnets natur og den praksis, det mønster af reaktioner og aktioner, som moderen som en del af en samfundsmæssig praksis formidler til barnet. Dette opgør med moderens praksis forholder sig som psykosociale formler analogt til ovennævnte psykofysiske mønster, men benævnes: Interaktion - Interaktionsform Interaktion. I denne interaktion, hvor moderen er formidler af samfundsmæssige praksisfigurer inddrages hun i en dialektisk proces med barnets indre natur, som bliver bestemmende for det psykofysiske indhold i barnets adfærd.

Det enkelte menneskes driftmatriks bliver fremstillet efter denne model, og den er i sine grundelementer resultatet af et opgør omkring kropsbehov, kropsformer og adfærdsmåder.

Hele dette mønster af adfærdsdeterminerende interaktionsformer er det ubevidste.

I følge Alfred Lorenzers koncept bliver det ubevidste $\mathrm{i}$ hver enkelt ontogenese fremstillet i et dialektisk opgør imellem barnets biologiske sociale muligheder, og hvad der reelt foregår i vekselspillet mellem mor og barn. Den totale intimitet imellem mor og barn brydes, og forholdet forandres når barnet efter fødselen kommer i kontakt med andre mennesker. Dette andet trin i personlighedsdannelsen er det, der går under betegnelsen familien. Ganske vist bliver formlerne i mor/barn enheden $\mathrm{i}$ barnets færden blandt andre mennesker ikke sat ud 
af drift, men den ændres og bliver mere differentieret.

Det tredie trin i socialisationsprocessen er egentlig ikke noget tredie trin, men mere et parallelt forløbende socialisationsaspekt.

Barnet og moderen er, ligegyldigt hvilket trin de bevæger sig på, en del af et kulturelt og materielt mønster, som ustandseligt præger forholdet. Når vi alligevel taler om det tredie trin i socialisationsprocessen er det fordi moderen og familien, set fra barnets position, ikke er hele verden. Det vokser også ind i en kultur, og er en del af en civilisationsproces, der har sin særlige form for knive og gafler, senge, stole, bygninger, gade, veje og byer - sæder og skikke osv. På trods af, ved siden af og samtidig med moderen, faderen, broderen, søsteren, onklerne, naboerne osv., eksisterer der ekstrafamiliære socialisationsfelter og symbolfigurer, som er væsentlige bestanddele af barnets livsspillerum. Disse såkaldte overgangsobjekter har en afgørende betydning for barnets personlighedsdannelse.

Byggeklodsen som barnet tager i hånden, skeen som det putter i munden, vognen som barnet skubber foran eller trækker efter sig, stolen som det sidder i, sengen som er grænsen for dets bevægelsesspillerum, dagligstuen som er dets aktionsradius, haven, gaden osv.. Alle disse genstande og rum har en struktur, og er som sådan handlingsanvisende betydningsbærere, bærere af adfærdsformler og anvisninger, som er formet af ekstrafamiliære, kollektive socialisationsinstitutioner; dvs. af de menneskeskabte symboler, og den måde kommunikation af viden praktiseres på under de herskende magtforhold.

Det vekselspil som eksisterer imellem mor og barn i familien og de samfundsmæssigt producerede materialitetsformer udgør, set fra barnets perspektiv, både som kropserfaring og oplevelsespanorama; de tids/rumslige sammenhænge, hvor dets personlighedsdannelse foregår.

De kollektive institutioner og sanselige symboler er i denne forbindelse betydningsfigurer, der knytter an til og udvider oplevelses- og interaktionsformerne i mor/barn dyaden. Mor barn dyaden bliver ikke sat ud af drift, men det gælder også her, den forandrer sig.

På alle de her nævnte trin og planer, dannes det ubevidste som struktur. Det trin som vi kalder bevidstheden bliver først nået $\mathrm{i}$ forbindelse med to videre skridt, hvor det første skridt i bevidsthedsdannelsesprocessen er førsprogligt.

Indsigten i dette trin i barnets personlighedsudvikling har Freud som tidligere næunt selv leveret. Freud beskriver i Jenseits des Lust- princip sine iagtagelser af sit barnebarns leg med en garnrulle. Legen består $i$ at barnet kaster en garnrulle der er bundet en snor i over sengekanten, og den forsvinder. Barnet trækker i snoren og garnrullen kommer tilbage. Både når garnrullen bliver borte, og er væk, og når den dukker op igen, bliver dens forsvinden og tilsynekomst fulgt af følelsesladede tilråb.

Lad os fra dette perspektiv vende tilbage til Alfred Lorenzers interpretation af Freuds skildring af barnebarnets leg med garnrullen. Barnets første symboldannelse, hvor det iscenesætter moderens kommen og gåen.

Das Kind war in seiner intellektuellen Entwicklung keinesweg voreilig, es sprach mit anderthalb Jahren erst wenige verständliche Worte und Verfügte außerdem über mehrere bedeutungsvolle Laute, die von der Umgebung verstanden wurden. Aber es war in gutem Rapport mit den Eltern und dem einzigen Dienstmädchen und 
wurde wegen seines >anständigen Charakters gelobt. Es störte die Eltern nicht zur Nachtzeit, befolgte gewissenhaft die Verbote, manche Gegenstände zu berühren und gewisse Räume zu gehen, und vor allem anderen, es weinte nicht, wenn die Mutter es für Stunden verließ, obwohl es dieser Mutter zärtlich anhing, die das Kind nicht nur selbst genährt, sondern auch ohne jede fremde Beihilfe geplegt und betreut hatte. Dieses brave Kind zeigte nun die gelegentlich störende Gewohnheit, alle kleinen Gegenstände, deren es habhaft wurde, weit weg von sich in eine Zimmerecke, unter ein Bett usw. zu schleudern, so daß das Zusammensuchen seines Spielzeuges oft keine leichte Arbeit war. Dabei brachte es mit dem Ausdruck von Interesse und Befriedigung ein lautes, langgezogenes o-o-o-o hervor, das nach dem übereinstimmenden Urteil der Mutter und des Beobachters keine Interjektion war, sondern >Fort< bedeutete. Ich merkte endlich, $d a \beta$ das ein Spiel sei, und daß das Kind alle seine Spielsachen nur dazu benützte, mit ihnen $>$ Fortsein $z$ u spielen. Eines Tages machte ich dann die Beobachtung, die meine Auffassung bestätigte. Das Kind hatte ein Holzspule, die mit einem Bindfaden umwickelt war. Es fiel ihm nie ein, sie zum Beispil am Boden hinter sich herzuziehen, also Wagen mit ihr zu spielen, sondern es warf die am Faden gestaltene Spule mit großem Geschick über den Rand seines verhängten Bettchens, so da $\beta$ sie darin verschwand, sagte dazu sein bedeutungsvolles o-o-o-o und zog dann die Spule am Faden wieder aus dem Bett heraus, begrüßte aber deren Erscheinen jetzt mit einem freudigen $>D a<$. Das war altso das komplette Spiel, Verschwinden und Wiederkommen, wovon man zumeist nur den ersten Akt zu sehen bekam, und dieser wurde für sich allein unermüdlich als Spiel wiederholt, obwohl die größere Lust unzweifelhaft dem Zweiten Akt anhing. ${ }^{24}$

Symboldannelse vil i denne forbindelse sige, at en scene, moderens gåen væk og kommen igen, bliver forbundet med en anden scene, som barnet identificerer sig med i legen med garnrullen.

Denne symboldannelse foregår på det førsproglige plan, og det kommer på dette tidspunkt ikke så meget an på om barnet er begyndt at tale eller ikke. Det afgørende er at begge dele af symboliseringen er en del af den samme sanselige erfaringsverden. Det er en erfaringsverden som er synlig og håndgribelig - som en garnrulle med en snor i og den er en del af det samme oplevelsesrum som moderen. Begge scener kan forbindes med en sanselig umiddelbar adfærd og handlen. Begge scener bliver registreret efter det samme mønster i hjernen og i kroppen på barnet. Det ene engram, scenen med moderen, bliver forbundet med det andet engram, scenen med garnrullen. Begge dele, scenen og iscenesættelsen, danner tilsammen et »sanseligt umiddelbart symbol«.

Dannelsen af sprogsymbolerne er det andet trin i bevidsthedsudviklingen, men med dem forholder det sig anderledes, da de to trin i bevidsthedsdannelsen er forskelligt indskrevet i kroppen og i hjernen.

Indføringen i sproget er også kendetegnet ved, at en sanselig erfaring i en bestemt situation, f.eks. omgangen med moderen bliver optaget som adfærdsspil, men nu bliver dette omsat ved at benævne det med et ord. Og det er et helt andet erfaringsfelt, fordi den cirkel der opstår imellem det opmærksomme $\varnothing$ re, og sprogzonerne i hjernen nu bliver knyttet med det lydgivende strubebånd. Det vil sige, at her bliver begge symbolers andele - hvis man se neurofysiologisk på situationen aflejret i hvert sit forskellige område af hjernen. De to praksis- 
firgurer tilhører også to vidt forskellige erfaringsområder. På den ene side omgangen med moderen, der er forbundet med adfærdsformler, der er knyttet til det sensomotoriske område, og sprogbillederne der må henføres til det sprogmotoriske område. Hvis vi bliver indenfor de kropslige eller nærmere bestemt neurofysiologiske differentieringer, kan vi sige, at vi har tre former for engrammer, der kan henføres til tre former for oplevelsesformationer og praksisfigurer. De kan deles således op:

1. Som det første trin af ubevidste sensomotoriske indskrivninger af ubevidste praksisfigurer og ubevidste oplevelses- og handleformer.

2. Som gruppen af sanselige umiddelbare symboler, eksemplificeret ved symbolet garnrulle og moderens kommen og gåen. Her forbindes to praksisfigurer med hinanden, som er knyttet på samme umiddelbare måde til situationen.

3. I den tredie gruppe af interaktionsformer bliver umiddelbare praksisengrammer forbundet med sprogformler.

Hvis vi endnu engang vender tilbage til, og ser på det kompleks af sanselige umiddelbare symboler af Winnicot kaldt overgangsobjekterne - og perspektiverer betydningen af disse i relation til vores tema, idrætten og arkitekturen som socialisationsinstitutioner, er der nogle aspekter ved disse overgangsobjekter, som er værd at fremhæve. Når den ene interaktionsform, spillet med garnrullen, står for en anden, nemlig samspillet med moderen, da fungerer garnrullen som betydningsbærer for forholdet imellem mor og barn; adfærdsformen mellem mor og barn. Det vi her foreløbeligt kalder overgangsobjekterne, det kan være teddybjørnen, boldene, billederne i billedbogen, der som sådan symboliserer det, der er afbildet. De henviser til genstande, som bliver fremstillet som scener, og dermed som mellemmenneskelige figurer. Det samme gælder for den vise, der bliver sunget, når barnet skal sove. Den symboliserer en livssituation.

Betragter vi under denne synsvinkel den verden, som barnet i det store hele oplever den, da kan vi sammenfattende sige, at de genstande, som befinder sig indenfor barnets domæne, som f.eks taburetten, sengen, stolen, skabet, bolden osv., adskiller nogle sig ved, at de tilbyder barnet legende og fantasifulde omgangsformer. Det vil sige barnets umiddelbare livsudkast kan inddrages enten i et aktivt eller passivt forhold i dets opgør med mennesker og omverden. Barnet kan via dem mestre dets intime måde at opleve verdenen på ved i forskellige livssituationer at knytte aktive forbindelser med overgangsobjekterne, der så fungerer som betydningsbærere. Det lyder måske indviklet, men taburetten som barnet sidder på, har en anden betydning - selvom det er den samme taburet - når den bliver skubbet omkring som en vogn.

Kollektivt påduttede og individuelt udviklede betydninger er hele tiden forbundet med hinanden i den betydningsbærende genstand. Ontogenesens sanselige og håndgribelige betydningsbærere er det fundament, der indenfor det store område af sanselige umiddelbare symboler, går under betegnelsen kunst og kropskultur. Disse symboler rækker lige fra idrætten til arkitekturen, fra musikken, skulpturen, maleriet, fotografiet og filmen til litteraturen.

\section{Teori og praksis}

Det er på baggrund af ovennævnte socialisationsteoretiske viden i forbindelse med kobling af teori og praksis i forskningsprocessen, at Alfred Lorenzer har udviklet 
en metodologisk reflekteret fremgangsmåde.

I relation til det metateoretiske koncept, der er den videnskabsteoretiske forudsætning for den psykoanalytiske kulturanalyse har Alfred Lorenzer udarbejdet en en kritisk hermeneutisk »verfahren « (fremgangsmåde), og introduceret et træningsforl $\varnothing \mathrm{b}$ og uddannelsesprogram for vordende kulturanalytikere. Et erfarings- og erkendelsesforl $\varnothing b$, som kandidater må gennemgå i stil med læreranalysen i den psykoanalytiske uddannelse.

Dette dybdehermeneutiske kulturanalytiske uddannelsesprogram skulle tjene flere formål. Det var vigtigt at få etableret en afklaret teoribaggrund, så man vidste, på hvilket grundlag man arbejdede. Det var afgørende, at man i praksis lærte ikke at belaste de forhold man analyserede med abstrakte begreber.

Den kritiske kulturanalyse betragter det som givet, at teori, teknik og interpretationspraksis er dynamiske vilkår i forbindelse med konkrete analyser. Det var vigtigt at lære at håndtere samspillet mellem teori, analyse og egen praksis. Jeg har sammen med en gruppe yngre forskere været med i dette projekt fra 1977 til Alfred Lorenzers alvorlige sygdom i 1989. Mit uddannelsesforløb strakte sig over 5 år. Det er i den sammenhæng, jeg har været med til at udvikle den interpretationsmetode, som Alfred Lorenzer kalder »die psychoanalytische tiefenhermeneutische Verfahren«. Under ledelse af Alfred Lorenzer har vi i et innovativt vekselspil med andre fag, som litteratur, billedkunst, religion, etnologi, antropologi, musik, film og arkitektur, arbejdet på at gøre psykoanalytiske erfaringer læs- og brugbare i et sociologisk og civilisationskritisk perspektiv. Det teoretiske og metodiske grundlag samt gruppens individuelle empiriske analyser er publiceret i bogen Kultur-Analysen.

\section{Den kritiske hermeneutiske kulturanalyse}

Kulturanalysen har ingen terapeutisk funktion. Den dybdehermeneutiske fremgangsmåde er i forbindelse med kunst- og kultursociologiske undersøgelsesfelter først og fremmest en ny måde at iagttage og opleve på, en ny teknik, et håndværk man må lære at bruge. Det interdisciplinære perspektiv ligger i, at man overfører dette forskningsmiddel på nye undersøgelsesfelter.

Hvis man vil opleve og erfare arkitekturen som et ekstrafamiliært socialisationsfelt $-d v s$. begribe arkitekturens subjektivitets- og kollektivitetsstiftende funktion så er en dør ikke bare en dør, en stol ikke bare en brugsgenstand, som man kan sidde på, men handlingsanvisende betydningselementer i et »sinnsystem《, som man må forsøge at forstå.

Når man foretager en hermeneutisk interpretation af ens oplevelser, om det er af et billede, en litterær tekst eller en arkitektonisk iscenesættelse, så er det muligt at erfare samfundsmæssige producerede oplevelsesfigurer som nedslag og resultat af sociale livsformer.

Selv om vi benytter os af erfaringer fra den psykoanalytiske praksis i vores måde at gå til værks på, så er fremgangsmåden selvfølgelig afhængig af det undersøgelsesfelt, som man vil analysere.

I en psykoanalytisk setting er det den fortalte tekst. I en interpretation af en litterær tekst er det den læste tekst. I en arkitekturinterpretation er det den oplevede arkitektoniske iscenesættelse. I en psykoanalyse undersøger man forholdet imellem psykoanalytiker og analysand. I en dybdehermeneutisk litteraturinterpretation er det tekst/læser forholdet. I en kritisk hermeneutisk arkitekturinterpretation forholdet 
imellem en arkitektonisk iscenesættelse og kulturanalytikerens oplevelse af dette intersubjektive mellemværende. Men ligegyldigt hvilket tema der analyseres, så er det vigtigt, at man begynder med metoden. En ny teori må opstå ud fra den egenlogik, der ligger i erkendelsesfeltet.

Det er også en forudsætning, at de oplevede scener og interpretationsfigurerne kan føres tilbage til og forbindes med det konkrete materiale, som er grundlaget for interpretationen. Hvis man føler, at proportionerne $\mathrm{i}$ et bygningsværk er kolossalt monumentale, skal rummene, vinduerne og dørene være overvældende og usædvanlig store. Hvis lyset opleves plat og koldt, skal det komme ovenfra og være uden skygger, som f.eks. monokromatiske lysrør i et helt hvidt rum.

En anden grund til, at det er så vigtigt selv at konstituere et sanseligt umiddelbart sammenspil med den arkitektoniske iscenesættelse er, at vi skal lære at udnytte de sanselige muligheder, som rækker udover de gældende sproglige normer. Man må ikke spærre for egne intuitive potentialer og forståelsen for arkitekturens betydning som sanseligt livsudkast og symbolsk adfærdsskitse, blot fordi man sanseløst overtager og bruger normerede sproglige udsagn. Udsagn der formaliserer en selv og det valgte tema under foreskrevne kategorier og konforme koder.

Man benytter sig derfor ikke af en logisk eller psykologisk forståelsesramme, men fors øger derimod at udvikle en scenisk forståelse, hvor man i oplevelsesprocessen udnytter de latente, men virksomme erkendelsespotentialer som kan henføres til ens egne visuelle, taktile, kinæstetiske og akustiske erfaringer med rum i situationsspil med lys, lyd, luft, rytme og bevægelse. Den sceniske forståelse opstår med den sceniske deltagelse i det umiddelbare ople- velses- og bevægelsesspil, hvor man overfører og fremstiller sine egne følelser, associationer, rumslige forventninger og iagttagelser i en stribe af sceniske beskrivelser. Man indsætter sine egne konkrete og sanselige livserfaringer som forudsætning for at kunne spore og dechifrere de fremmede livsudkast, som kulturtilbuddet præsenterer.

Det særlige ved fremgangsmåden er, at man på en gang både deltager og prøver at forstå sin medvirken i det sanselige spil, i den figuration, man som interpret er blevet involveret i. Denne dobbelte manøvrering er ikke et forløb, hvor man benævner det, der sker fra to sider, men derimod kendetegner den som to uadskillelige, men alligevel med hinanden sammenfiltrede og konvergerende anlagte operationer, der foregår på to planer i to forskellige medier. Den kritiske hermeneutiske opereren bevæger sig i mediet sprog. Den kan ikke bevæge sig på andre planer, hvorimod deltagelsen i overførings- og modoverføringsspillet foregår på det plan, som er karakteriseret ved det sanselige umiddelbare sammenspil; det sammenspil som sætter af fra kroppen, og ikke blot åbner, men også inddrager hele det repertoire af sanselige erfaringer, som rækker udover den gældende sproglige orden.

At man med den sceniske forståelse indlader sig på et livspraktisk forhold betyder, at oplevelsesspillerummet og vekselspillet imellem de individuelle livsudkast, protosymbolerne og de kollektive handlingsanvisende kultursymboler, kan tydes såvel $\mathrm{i}$ et livspraktisk som kritisk perspektiv. Sprogets elaborerede sammenkædning forbliver irreal, indtil det skridt for skridt bliver realiseret i forbindelse med en real interageren. Det er over den sceniske konfrontation, at man i selve fortolkningsprocessen får den virkning bragt på ord, som 
arkitekturen og dermed forbundne aktiviteter har på brugeren. De umiddelbare oplevelser bliver symboliseret ved hjælp af sproget. Det der bliver analyseret er hverken arkitekten eller arkitekturen, men den virkning som den arkitektoniske iscenesættelse som kollektivt symbolsystem har på interpreten.

Samspillet med arkitekturen er hverken en subjektiv fortælling eller en objektiv registrering, det er en intersubjektiv oplevelse af en konkret kulturel iscenesættelse. Det er ikke en subjektiv oplevelse ej heller en objektiv beskrivelse, men et intersubjektivt mellemværende. Det er gennem sproget, at den (æstetiske) sansede oplevelse får sin værdi. Der er ikke tale om en evaluering, men en sanselig kropslig erfaring, der må gøres tilgængelig for fællesskabet i sprog og billeder.

\section{Afsluttende bemorkninger}

De sanselige aktiviteter fordrer kropslig selvstændighed, ikke bare hos barnet, men også hos den voksne. Menneskets socialisering hænger sammen med socialiseringsog symboliseringsprocesser, der kan be- væge eller hæmme mennesker gennem hele livet. Det afhænger af om vedkommende er parat til at udnytte sine livsudkast og sanselige ressourcer i et samspil med mennesker og omverden. Om han eller hun tør reflekterer sin praksis gennem kritiske og dynamiske orienteringsmidler. Socialiseringen og symboliseringen samt udfoldelsen af den enkeltes personlighedsstruktur og den kulturelle udvikling afhænger af, om den pågældende bevæger sig $\mathrm{i}$ en proces, der fremmer en vitalisering af teori og praksis, eller forholder sig passivt og indordner sig under de givne normer. De normer der kræver, at man repeterer konforme koder, som enten refererer til fastlagte teorier eller bekræftiger den etablerede videnskabelige konsensus, og dermed styrker omstændigheder, hvor aktørerne stivner, og bliver til tænkende statuer i abstraktionernes uforpligtende tåger.

Det handler om desymbolisering eller resymbolisering, om dræbende gentagelser af det stillestående eller om en revitalisering af de potentialer i alles liv, der har deres rødder i de konkrete oplevelser, der følger med bevægelsen mod ny erkendelse. 


\section{Noter}

1. Norbert Elias: The Symbol Theory, London 1991.

2. Steen Eiler Rasmussen: London, s. 305, København 1934.

3. ibid., s.316.

4. ibid., s.340.

5. ibid., s.340-45.

6. Steen Eiler Rasmussen: Omkring Sportens Æstetik i Tidsskrift for Legemsøvelser s.50, København 1941.

7. Steen Eiler Rasmussen: Om at opleve arkitektur., s. 8, København 1957.

8. Steen Eiler Rasmussen: Michelangelo og Fodbold fra 1939 i Essay gennem mange år, København 1968.

9. Steen Eiler Rasmussen (1957) op.cit., s 24.

10. ibid., s.29.

11.ibid., s.32.

12. Sigmund Freud: Das Unbewußte i Gesammelte Werke, London, Bd.X s.300.

13. Sigmund Freud: Zur Auffassung der Aphasien, Leipzig/Wien 1891. Citeret efter Alfred Lorenzer:

\section{Litteratur}

Norbert Elias: The Symbol Theory, London 1991.

Sigmund Freud: Zur Auffassung der Aphasien, Leipzig/Wien 1891.

Sigmund Freud: Das Unbewußte i Gesammelte Werke, London, Bd. X.

Sigmund Freud: Jenseits des Lustprinzips i Gesammelte Werke Bd. XVII.

Jørn Hansen og Søren Nagbøl: Ollerup College of Physical Education - Living Space - Culture of Movement and Social Identity. 50 sider i Bewegungsräume. Körperanthropologische Beiträge, Afra Verlag. Butzbach-Griedel 1996.

Kultur-Analysen: Hans-Dieter König, Alfred Lorenzer, Heinz Lüdde, Søren Nagbøl, Ulrike Prokop, Gunzelin Schmied Noerr/Annelinde Eggert. Frankfurt a/M 1986.

Alfred Lorenzer: Zur Bergründung einer materialistischen Sozialisationstheorie. Frankfurt a/M 1973.

Alfred Lorenzer: Die Wahrheit der Psychoanalytischen Erkenntnis. Ein historisch-materialistischer Entwurf, Frankfurt a/M 1974.

Alfred Lorenzer, Alfred Schmidt og Bernhard Görlich: Der Stachel Freud., s. 312, Frankfurt a/M 1980.

Alfred Lorenzer: Das Konzil der Buchhalter. Die Zerstörung der Sinnlichkeit. Eine Religionskritik, Frankfurt a/M 1981.
Tiefenhermeneutische Kulturanalyse i KulturAnalysen. Hans-Dieter König, Alfred Lorenzer, Heinz Lüdde, Søren Nagbøl, Ulrike Prokop, Gunzelin Schmied Noerr/Annelinde Eggert. Frankfurt a/M 1986.

14. ibid., s.79.

15. Alfred Lorenzer (1986) op.cit., s. 42.

16. ibid., s. 46 .

17. Alfred Lorenzer: Der Stachel Freud., s.312, Frankfurt 1979.

18. Alfred Lorenzer (1986) op.cit., s.47.

19. Sigmund Freud (1891) op.cit., s.79. Citeret efter Alfred Lorenzer (1986)

20. ibid., s.76.

21. ibid., s.75.

22. ibid., s.78.

23. Sigmund Freud: Jenseits des Lustprinzips i Gesammelte WerkeXVII, s.11-13.

24. ibid.

Søren Nagbøl: Macht und Architektur. Versuch einer erlebnisanalytischen Interpretation der Neuen Reichskanzlei i Kultur-Analysen, s. 347-374: Psychoanalystische Studien zur Kultur. Hans-Dieter König. Alfred Lorenzer, Heinz Lüdde, Søren Nagbøl, Ulrike Prokop, Gunzelin Schmied Noerr/Annelinde Eggert. Frankfurt a/M 1986.

Søren Nagbøl: Diziplinierung in Weiss. Eine Architekturinterpretation, s. 347-366 med 11 fotografier i: Zur Idee einer psychoanalystishen Sozialforschung. Frankfurt a/M 1987.

Søren Nagbøl: At bade er regionalt, nationalt og overnationalt. Helgoland på Amager, s. 24-32 i: Kropskultur og idræt. Idrætshistorisk årbog 1990.

Søren Nagbøl: Enliving and deadening shadows. Understanding architectural experiences, 18 sider med 4 fotografier i Sport and Place, International Review for the Sociology of Sport, maj 1993.

Søren Nagbøl: Berøvende Arkitektur. En oplevelsesanalyse af Arkitekturmuseet i Frankfurt a/M. København 1994.

Søren Nagbøl: Konstrueret virkelighed. En oplevelsesanalyse der berører arkitekturen, litteraturen, billedkunsten, medierne, virkeligheden og os, i Matrix Nordisk Tidsskrift for psykoterapi, København 12. Årgang Nr 1 August 1995. 
Steen Eiler Rasmussen: London, København 1934.

Steen Eiler Rasmussen: Om at opleve arkitektur,

København 1957.
Steen Eiler Rasmussen: Essay gennem mange år, København 1968.

D. W. Winnicot: The Maturational Processes and the Facilitating Environment, London 1965. 